\title{
Application of Electromagnetic Sensing and Infiltration Measurements to Evaluate Salinity Reclamation and Turfgrass Management Options for Improved Leaching
}

Gülüzar Duygu Semiz ( $\sim$ semiz@ankara.edu.tr)

Ankara University

Donald L. Suarez

USDA-ARS U.S. Salinity Laboratory

Scott Lesch

Riverside Public Utilities Resource Division

\section{Research Article}

Keywords: EM38, ESAP, turfgrass, salinity mapping, leaching, golf course

Posted Date: April 21st, 2021

DOI: https://doi.org/10.21203/rs.3.rs-439724/v1

License: (c) (i) This work is licensed under a Creative Commons Attribution 4.0 International License.

Read Full License 


\section{Abstract}

Scarce freshwater resources in arid and semiarid regions means that recreational landscapes should use recycled or low quality waters for irrigation, increasing the risk of salinity and infiltration problems. We map salinity distribution within turf fields using electromagnetic sensing, evaluate need for leaching and evaluate post leaching results for subsequent management decisions. Electromagnetic measurements were made with two EM38 instruments positioned vertically and horizontally in order to determine salinity distribution. Sensor readings were coupled to GPS data to create spatial salinity maps. Next, optimal calibration point coordinates were determined via ESAP software. Soil samples were taken from 0-60 cm at 5 depths for each calibration point. Laboratory soil saturation percentage, moisture content, ECe and pHe of saturation extracts were determined for calibration to convert resistivity measurements to ECe. Next, ECe maps were created using ESAP software. Leaching for reclamation was performed by means of sprinkling. Treated municipal wastewater was utilized both for irrigation and for reclamation leaching. Low water content and high spatial variability of soil texture adversely affected the accuracy of the readings. Pre and post leaching surveys indicate that there was only a $30 \%$ decrease in salinity, very low relative to expected results considering the amount of water applied. This relatively low reduction in salinity and the lack of runoff during irrigation combined with infiltration measurements suggests that aeration techniques for healthier grasses led to water bypassing small pores thus limiting leaching efficiency. In this instance practices to improve infiltration lead paradoxically to less salinity reclamation than expected.

\section{Introduction}

Increasing soil salinization and scarce freshwater supplies in arid and semi-arid regions means that whenever possible more saline lower quality waters should be used in agriculture, saving fresh water for municipal use. This substitution of lower quality water is especially important when biomass yield is not important, such as with recreational turfgrass. Use of these waters requires careful monitoring of salinity. Assessment of soil salinity has been determined in a number of ways: (i) plant observations, (ii) the electrical conductance of soil solution extracted via soil water extractors (iii) the electrical conductivity (EC) of water obtained by collecting soil samples, adding varying amounts of water to each sample and then extracting, (iv) in situ measurement of electrical resistivity (ER), (v) non-invasive determination of EC with electromagnetic induction (EMI), and most recently (vi) in situ determination of EC with time domain reflectometry (TDR). The techniques of ER, EMI, and TDR measure bulk soil electrical conductance, termed $\mathrm{EC}_{\mathrm{a}}{ }^{[1]}$.

Compared to other methods, EMI measurements generate both spatially and temporally highly efficient data ${ }^{[2]}$. However in contrast to the other methods EMI and ER have the disadvantage of requiring calibration to convert the data to soil water or saturation extract $\mathrm{EC}\left(\mathrm{EC}_{\mathrm{e}}\right)$.

In the last 20 years, scientists have made advances to better understand the best application procedure for measuring soil salinity, water in soil pores, soil texture and depth etc. ${ }^{[3,4,5,6,7,8]}$. By identifying the 
complexities of $\mathrm{EC}_{\mathrm{a}}$ measurement and how to deal with them, Corwin and Lesch ${ }^{[9]}$ provided guidelines for the use of $\mathrm{EC}_{\mathrm{a}}$ in agriculture. EM38 is a tool that measures $\mathrm{EC}_{\mathrm{a}}$ value of approximately $0.75-1.5 \mathrm{~m}$ depth of the soil profile, depending on its horizontal and vertical positioning. This device consists of a receiver and a transmitting coil placed at opposite ends of the non-conductive rod at $1 \mathrm{~m}$ intervals ${ }^{[10]}$. The EMI technique produces readings on any conductive surface as $\mathrm{EC}_{a}, \mathrm{EC}_{\mathrm{a}}$ readings can be influenced not only by soil salinity, but also by any property that affects conductivity such as soil water content and clay content. Calibration equations between $\mathrm{EC}_{\mathrm{a}}$ and $\mathrm{EC}_{\mathrm{e}}$ should be established taking into account sitespecific properties such as soil texture, soil water content, soil salinity etc in an area measured by the EM technique. Three parallel pathways of current flow contribute to the $\mathrm{EC}_{\mathrm{a}}$ measurement: 1) a liquid phase pathway via dissolved salts contained in the soil water present in medium to large pores, 2) a solid phase pathway via conduction through soil particles that are in continuous, direct contact with one another, and 3) a solid-liquid pathway via hydrated exchangeable cations associated with clay minerals ${ }^{[11]}$.

Remote sensing has made the concept of precision agriculture practical. Precision agriculture utilizes detailed maps of soil or vegetative characteristics for site specific management ${ }^{[12]}$. Among the soil properties and characteristics of most interest are water content, soil texture and salinity. Precision agriculture has been applied to landscape vegetation as well as agriculture. Carrow ${ }^{[13]}$ et al. used the term precision turfgrass management (PTA) for application of the site specific mapping concepts to turfgrass management of irrigation, salinity and fertilizer application and cultivation, utilizing both soil sampling and various field based sensors. Devitt ${ }^{[14]}$ et al., evaluated the spatial and temporal changes in salinity on turfgrass using insitu sensors. This approach provides more accurate data than that obtained via remote sensing but has limited practicality due to cost of installation and need for many sensors to characterize variability.

To evaluate soil salinity we are interested primarily in the electrical conductance of the soil solution. The $\mathrm{EC}_{\mathrm{a}}$ measurement includes more than just soil salinity, as it is a measure of the sum of all conductive materials within the volume of measurement and is thus influenced by any soil property that affects bulk soil electrical conductance ${ }^{[13]}$. Use of a $\mathrm{EC}_{\mathrm{a}}$ survey to measure salinity within an area has been divided into eight steps: (1) design for the $\mathrm{EC}_{\mathrm{a}}$ survey, (2) spatially identified $\mathrm{EC}_{\mathrm{a}}$ data collection (3) soil sampling design based on the spatial variations in the $\mathrm{EC}_{\mathrm{a}}$ data (4) collection of soil samples at the identified optimal sites for $\mathrm{EC}_{\mathrm{a}}$ calibration (5) physical and chemical analysis of relevant soil properties, primarily EC of a soil water extract, (6) spatial statistical analysis (7) determination of main soil properties in the study area affecting the $\mathrm{EC}_{\mathrm{a}}$ measurements (8) GIS application ${ }^{[15]}$. The U.S. Salinity Laboratory Staff (ARS-USDA, Riverside, California) developed conductivity modeling software (Electrical conductivity Sampling Assessment and Prediction-ESAP $)^{[16,17,18,19,20]}$ to promote efficiency acquisition and construction of $\mathrm{EC}_{\mathrm{a}}$ data. ESAP, user-friendly software, provides (i) survey maps and directed sample design relying on the maps (ii) calibration of $\mathrm{EC}_{\mathrm{a}}$ readings to $\mathrm{EC}_{\mathrm{e}}$ (iii) explication of estimated spatial salinity data. Acquired information is practical for salinity management ${ }^{[20]}$. 
The aim of this study is to map the salinity distribution of two fairways at Dove Canyon golf course in Trabuco Canyon, California by means of EM38 sensors in order to determine need for reclamation and then remap the fairways to evaluate the success of attempted soil remediation via leaching. This report represents a use of the EM technique to enable faster diagnosis of salinity in golf courses with minimal detrimental soil disturbance from soil coring, critical to recreational turf.

\section{Results And Discussion \\ 2.1. Leaching}

The reference crop evapotranspiration ( $\mathrm{ET}_{0}$ ) during July was $5.55 \mathrm{~mm} \mathrm{~d}^{-1}$ (CMIS station 75 ) with regular irrigation application averaging $3.9 \mathrm{~mm} \mathrm{~d}^{-1}$. Water application was thus $70 \%$ of potential ET. Under irrigation would result in slower growth and reduced plant density but by itself does not explain the poor turf status,

The initial extra water event for soil reclamation was initiated on 7/16-7/19 (4 nights and 3 days). Sprinklers were run on 20 minute cycles, with at least a 20 minute period in between each cycle. The calculated applied water for the 7/16 - 7/19 leaching event was $152.8 \mathrm{~mm}$. In addition $11.7 \mathrm{~mm}$ of water were applied during this period to compensate for ET. Leaching water was the same source as irrigation water; municipal treated wastewater. In addition to these EM 38 measurements we also collected soil samples and infiltration data for fairway 12 after leaching with an additional $101 \mathrm{~mm}$ of water.

\subsection{Field Survey and Salinity Mapping}

The salinity survey was divided into two parts, pre-leaching and post-leaching surveys. In the pre-leaching survey, EM38 readings (both $\mathrm{EM}_{\mathrm{v}}$ and $\mathrm{EM}_{\mathrm{h}}$ data) were saved simultaneously with GPS data on a data logger mounted on the vehicle (Fig. 1a), thus each reading was associated with spatial data. After the transect readings and GPS data were collected, The ESAP RSSD module was run to develop the sampling design. The program determined 10 sampling points as shown in Fig. 2 for fairway 16 with GPS coordinates. We navigated to each sampling coordinates and collected soil cores by means of a hydraulic soil corer attached to the vehicle (Fig. 1b). The system had a metallic column to break down the soil's mechanic resistance and a plastic column sleeve inside to take the soil samples. Totally, 10 plastic columns with a height of $60 \mathrm{~cm}$ were taken to the lab from each fairway.

The results of the soil analyses and the EM data were run on ESAP module CALIBRATE and then the program generated outputs via ESAP SALTMAPPER module as $\mathrm{EC}_{\mathrm{e}}$ salinity maps and ASCIl data. These same processes including EM38 transect readings and ESAP- SALTMAPPER were carried out after leaching (post-leaching). 
The $\mathrm{EC}_{\mathrm{e}}$ results of the soil samples for fairway 16 , for both pre and post-leaching are giving in Table 1 and the results from fairway 12 in Table 2 . We used a standard multiple linear regression (MLR) model defined as below.

$\ln \left(E C_{e}\right): \beta_{0}+\beta_{1} \ln \left(E M_{v}\right)+\beta_{2} \ln \left(E M_{h}\right)[1]$

Where: $\mathrm{EC}_{\mathrm{e}}$ is the soil salinity, $\mathrm{EM}_{\mathrm{v}}$ and $\mathrm{EM}_{\mathrm{h}}$ are the vertical and horizontal reading respectively, and $\beta_{0}, \beta_{1}$, and $\beta_{2}$ are model parameters. Data were further corrected for variations in water content based on water content of the soil samples via ESAP.

Table 1

Soil salinity at the sampling points for pre and post leaching for fairway 16 .

\begin{tabular}{|c|c|c|c|c|c|c|c|}
\hline $\begin{array}{l}\text { Sample } \\
\text { Point }\end{array}$ & $\begin{array}{l}\text { Depth } \\
\text { (cm) }\end{array}$ & $\begin{array}{l}\text { Pre } \\
\text { Leaching } \\
\text { EC }_{e} \\
\left(\mathrm{dSm}^{-1}\right)\end{array}$ & $\begin{array}{l}\text { Post } \\
\text { Leaching } \\
\mathrm{EC}_{\mathrm{e}} \\
\left(\mathrm{dSm}^{-1}\right)\end{array}$ & $\begin{array}{l}\text { Sample } \\
\text { Point }\end{array}$ & $\begin{array}{l}\text { Depth } \\
\text { (cm) }\end{array}$ & $\begin{array}{l}\text { Pre } \\
\text { Leaching } \\
\mathrm{EC}_{\mathrm{e}} \\
\left(\mathrm{dSm}^{-1}\right)\end{array}$ & $\begin{array}{l}\begin{array}{l}\text { Post } \\
\text { Leaching }\end{array} \\
\mathrm{EC}_{\mathrm{e}} \\
\left(\mathrm{dSm}^{-1}\right)\end{array}$ \\
\hline \multirow[t]{2}{*}{18} & $0-15$ & 5.68 & 7.28 & 164 & $0-15$ & 18.8 & 9.35 \\
\hline & $15-30$ & 10.90 & 2.39 & & $15-30$ & 9.9 & 2.66 \\
\hline \multirow[t]{2}{*}{57} & $0-15$ & 20.5 & 5.11 & 263 & $0-15$ & 10.43 & 6.44 \\
\hline & $15-30$ & 10.3 & 11.57 & & $15-30$ & 8.55 & 7.19 \\
\hline \multirow[t]{2}{*}{87} & $0-15$ & 6.7 & 1.93 & 268 & $0-15$ & 6.27 & 3.34 \\
\hline & $15-30$ & 2.5 & 1.36 & & $15-30$ & 6.96 & 2.05 \\
\hline \multirow[t]{2}{*}{155} & $0-15$ & 13.2 & 8.84 & 350 & $0-15$ & 16.58 & 13.53 \\
\hline & $15-30$ & 9.4 & 1.26 & & $15-30$ & 36.1 & 11.32 \\
\hline
\end{tabular}

Pre and Post leaching EM38 data exhibit very high spatial consistency. Post leaching average EM levels increase slightly relative to pre leaching values $\left(\mathrm{EM}_{\mathrm{v}}: 77.5\right.$ to $80.0 \mathrm{mSm}^{-1} ; \mathrm{EM}_{\mathrm{h}}: 62.6$ to $\left.72.3 \mathrm{mSm}^{-1}\right)$. Both apparent reductions in EM readings are statistically significant $(p<0.05)$. The $15-30 \mathrm{~cm}$ leaching effect appears to be slightly more pronounced than the $0-15 \mathrm{~cm}$ effect. This suggests preferential flow or by bass in the near surface environment and or under irrigation.

The salinity values for the soil cores taken in fairway 16 (Table 1) show a wide range in EC, varying from $E_{e} 5.68$ to $20.5 \mathrm{dS} \mathrm{m}^{-1}$ in the $0-15 \mathrm{~cm}$ depth and from $\mathrm{EC}_{\mathrm{e}} 2.5$ to $36.1 \mathrm{dS} \mathrm{m}^{-1}$ in the $15-30 \mathrm{~cm}$ samples. Mean salinity level for the soil samples collected from fairway 16 before leaching was $\mathrm{EC}_{e}$ 13.13 and $12.52 \mathrm{dSm}^{-1}$ for $0-15$ and $15-30 \mathrm{~cm}$ depth respectively. These samples can be considered biased in that the sample locations were not random but rather selected by the ESAP software to capture the variability observed in the $\mathrm{EM}_{\mathrm{a}}$ maps. The median $\mathrm{EC}_{\mathrm{e}}$ values based on the $\mathrm{EM}$ reading converted to $\mathrm{EC}_{\mathrm{e}}$ were $12.5 \mathrm{dS} \mathrm{m}^{-1}$ for $0-15 \mathrm{~cm}$ depth and $8.5 \mathrm{dS} \mathrm{m}^{-1}$ for $15-30 \mathrm{~cm}$ depth. 
As shown in Fig. 3a. in the salinity map for fairway 16 , there was considerable variation in salinity in the 0-15 cm depth with about $50 \%$ of the fairway above $\mathrm{EC}_{\mathrm{e}}=5 \mathrm{ds} \mathrm{m}^{-1}$ and an extensive area above $\mathrm{EC}_{\mathrm{e}}=$ $18 \mathrm{dS} \mathrm{m}^{-1}$ a value where the turf would be severely impacted. The salinity map for 15-30 cm depth (Fig. 3b) shows reduced salinity relative to the soil surface, suggesting a lack of sufficient leaching with current irrigation regime, consistent with the measured water applications being below ET. At both depths the salinity is greater in the lower portion of the fairway suggesting the potential for differential leaching in these two regions.

The measured salinity levels are high enough to cause a decrease in visual quality of Bermuda grass hence the decision to leach the soil. Bermuda grass has a salinity threshold level of $\mathrm{EC}_{\mathrm{e}} 6.9 \mathrm{dS} \mathrm{m}^{-1}$ above which there is loss of vegetative growth ${ }^{[21]}$ but not until $\mathrm{EC}_{\mathrm{e}} 15 \mathrm{dS} \mathrm{m}^{-1}$ does the grass drop below a rating of 6 for visual quality ${ }^{[22]}$ and growth is reduced by $50 \%{ }^{[23]}$. Xiang ${ }^{[24]}$ et al., documented a drop in live green cover for several Bermuda grasses from greater than $80 \%$ at EC $\leq 15 \mathrm{dS} \mathrm{m}^{-1}$ to less than $50 \%$ at $E C \geq 15 \mathrm{dS} \mathrm{m}^{-1}[25]$. The $E_{\mathrm{e}}$ results of the soil samples for fairway 12 , pre leaching are given in Table 2. The salinity values show a wide range in $\mathrm{EC}$, varying from $\mathrm{EC}_{\mathrm{e}} 2.37$ to $13.3 \mathrm{dS} \mathrm{m}^{-1}$ in the $0-15$ $\mathrm{cm}$ depth and from $\mathrm{EC}_{\mathrm{e}} 1.22$ to $15.1 \mathrm{dS} \mathrm{m}^{-1}$ in the $15-30 \mathrm{~cm}$ samples. Mean salinity for the soil samples collected from fairway 12 before leaching were $\mathrm{EC}_{\mathrm{e}} 8.46$ and $6.77 \mathrm{dSm}^{-1}$ for $0-15$ and $15-30 \mathrm{~cm}$ depth respectively. Material below this depth consisted of relatively unweathered rock and was not collected.

Table 2

Soil salinity at the sampling points for pre and post leaching for fairway 12

\begin{tabular}{|c|c|c|c|c|c|c|c|}
\hline $\begin{array}{l}\text { Sample } \\
\text { Point }\end{array}$ & $\begin{array}{l}\text { Depth } \\
\text { (cm) }\end{array}$ & $\begin{array}{l}\text { Pre } \\
\text { Leaching } \\
\mathrm{EC}_{\mathrm{e}} \\
\left(\mathrm{dSm}^{-1}\right)\end{array}$ & $\begin{array}{l}\text { Post } \\
\text { Leaching } \\
\mathrm{EC}_{\mathrm{e}} \\
\left(\mathrm{dS \textrm {m } ^ { - 1 }}\right)\end{array}$ & $\begin{array}{l}\text { Sample } \\
\text { Point }\end{array}$ & $\begin{array}{l}\text { Depth } \\
\text { (cm) }\end{array}$ & $\begin{array}{l}\text { Pre } \\
\text { Leaching } \\
\text { EC }_{\mathrm{e}} \\
\left(\mathrm{dSm}^{-1}\right)\end{array}$ & $\begin{array}{l}\text { Post } \\
\text { Leaching } \\
\text { EC }_{e} \\
\left(\mathrm{dSm}^{-1}\right)\end{array}$ \\
\hline \multirow[t]{2}{*}{11} & $0-15$ & 10.47 & 13.90 & 214 & $0-15$ & 13.27 & 8.88 \\
\hline & $15-30$ & 8.66 & 9.22 & & $15-30$ & 6.28 & 2.93 \\
\hline \multirow[t]{2}{*}{47} & $0-15$ & 19.52 & 4.81 & 218 & $0-15$ & 2.37 & 3.93 \\
\hline & $15-30$ & 4.90 & 4.78 & & $15-30$ & 2.35 & 2.43 \\
\hline \multirow[t]{2}{*}{94} & $0-15$ & 6.62 & 2.50 & 279 & $0-15$ & 13.82 & 2.13 \\
\hline & $15-30$ & 15.13 & 5.65 & & $15-30$ & 10.98 & 1.32 \\
\hline \multirow[t]{2}{*}{168} & $0-15$ & 9.54 & 2.66 & 303 & $0-15$ & 2.7 & 5.59 \\
\hline & $15-30$ & 9.07 & 2.27 & & $15-30$ & 2.4 & 2.26 \\
\hline \multirow[t]{2}{*}{188} & $0-15$ & 2.94 & 5.33 & 345 & $0-15$ & 3.32 & 3.21 \\
\hline & $15-30$ & 1.22 & 5.9 & & $15-30$ & 2.22 & 3.18 \\
\hline
\end{tabular}


Based on the $\mathrm{EC}_{\mathrm{e}}$ map generated, we calculate that $10 \%$ of the fairway had an $\mathrm{EC}_{\mathrm{e}}$ greater than $6.9 \mathrm{dS} \mathrm{m}^{-}$

1 , thus less than $10 \%$ had salinity levels that would cause either significant reduction in growth or unacceptable turf appearance. In this fairway most of the poor turf condition is attributed to shallow soil with insufficient water holding capacity, resulting in likely water stress between irrigations. The detailed $E_{e}$ map based on the EM survey is shown in Fig. $4 a$ and $4 b$ for $0-15$ and $15-30 \mathrm{~cm}$ depth, respectively, providing information on the spatial distribution of the salinity.

\subsection{Post Leaching Salinity \\ 2.3.1. Fairway 16}

After leaching the mean salinity level for fairway 16 was 7.49 and $5.39 \mathrm{dS} \mathrm{m}^{-1}$ for $0-15$ and $15-30 \mathrm{~cm}$ respectively (based on data in Table 1). The reduction in average soil salinity is statistically significant $p$ $<0.05$. The salinity based on soil cores decreased by $43 \%$ for the $0-15 \mathrm{~cm}$ depth and by $57 \%$ for the $15-$ $30 \mathrm{~cm}$ depth after application of $153 \mathrm{~mm}$ of water. This suggests inefficient leaching because the expected decrease in salinity would be predicted to be much greater than observed. For example, according to relations developed by Keren and Miyamoto ${ }^{[26]}$ for intermittent ponding, the calculated depth of leaching water divided by soil depth, 2.02 for $0-15 \mathrm{~cm}$ and $0.68 \mathrm{for} 15-30 \mathrm{~cm}$ depth should have resulted in salinity level decreases of $95 \%$ and $83 \%$ respectively or mean $\mathrm{EC}_{\mathrm{e}}$ values of 0.66 and $2.13 \mathrm{dS}$ $\mathrm{m}^{-1}$, respectively. The very limited effect of water application on soil salinity is attributed to water bypass. This hypothesis is reinforced by the relatively poor leaching in the $0-15 \mathrm{~cm}$ depth as compared to leaching in the $15-30 \mathrm{~cm}$ depth, as well as the use of mechanical aeration paradoxically utilized to improve water penetration. Post leaching, the mean salinity level of the fairway was well below the threshold level at which Bermuda grass would be affected. However the limitation of using mean values is indicated by the $\mathrm{EC}_{\mathrm{e}}$ maps (Fig. $3 \mathrm{c}$ and d), as many regions of the fairway were still adversely affected at both $0-15$ and $15-30 \mathrm{~cm}$ depth. The salinity maps were generated by dividing the calculated $\mathrm{EC}_{\mathrm{e}}$ values into quartile salinity distributions. Comparing Fig. 3a (pre leaching) and 3c (post leaching) for the 0-15 cm depths, we note the striking similarity of the spatial distribution or salinity patterns. The salinity levels were reduced in all areas but the higher salinity areas remained higher after leaching. In this instance we see the potential benefit of site specific management (leaching) but unfortunately the current irrigation system could not be easily modified to use the leaching water more effectively.

\subsubsection{Fairway 12}

The mean salinity levels $\left(E C_{e}\right)$ based on soil cores for fairway 12 after leaching were $5.29 \mathrm{dS} \mathrm{m}{ }^{1}$ for the 0-15 cm depth and 3.99 for the $15-30 \mathrm{~cm}$ depth. The $20 \%$ calculated reduction in average soil salinity was statistically significant $(p<0.05)$, however the salinity reduction was much less than expected based on applied water, suggesting as was the case in fairway 16 , that water bypass limited salinity leaching. The mean salinity levels are below the threshold level at which Bermuda grass would be affected by salinity. As indicated by the post leaching map, shown in Fig. $4 \mathrm{c}$ and d, only small portions of the fairway (upper portions of Fig. 4c) were still adversely affected by salinity $\left(E_{e}>8.7 \mathrm{dS} \mathrm{m}^{-1}\right)$. 
The measured infiltration rate based on the Guelph permeameters varied between $3.5 \mathrm{~mm} \mathrm{~h}^{-1}$ to $264 \mathrm{~mm}$ $\mathrm{h}^{-1}$ with a mean value of $76 \mathrm{~mm} \mathrm{~h}^{-1}$ at the soil surface and between 1.5 and 0.3 with a mean value of $1.11 \mathrm{~mm} \mathrm{~h}^{-1}$. Most of the field is estimated to have an infiltration rate lower than the sprinkler application rate $17 \mathrm{~mm} \mathrm{~h}^{-1}$. There was no evidence of surface runoff during irrigation. It seems reasonable that some water redistribution might occur during irrigation but this is not sufficient to explain the lack of complete leaching that would be expected for the $0-15 \mathrm{~cm}$ depth after $264 \mathrm{~mm}$ of leaching water $\left(\mathrm{EC}_{\mathrm{e}}=\right.$ $0.6 \mathrm{dS} \mathrm{m}^{-1}$, would be in equilibrium with the irrigation water salinity). Also, we did not observe surface runoff during irrigation nor was there any evidence of surface erosion despite slopes exceeding $5 \%$ in some areas and with all permeameter values below the irrigation rate at the $15-18 \mathrm{~cm}$ depth. As with fairway 16 , we can only consider that concurrent aeration practices resulted in large macropore flow. The poor turf quality in this fairway is likely the result of water bypass at the surface resulting in intermittent water stress between irrigation events rather than elevated salinity.

\section{Discussion}

Soil salinity exhibits not only a complex pattern in the field that cannot be readily captured by conventional soil sampling but is also temporally variable. Traditional assessment of soil salinity in the field scale is very time consuming and labor dependent on both laboratory and field studies. The sensing equipment is demonstrated to provide detailed and relatively rapid mapping but accurate calibration is not always simple. Accurate mapping requires site specific calibration and may still fail to provide a good calibration between soil samples and sensor readings. In this study, we briefly describe the current best approaches for calibration and evaluate the methodology for a field study with EM survey and data actuation for grass landscapes. In regions with water shortages, such as Southern California, USA, the spatial distribution of salinity is extremely important for reducing the amount of leaching water where reclamation is needed. In these areas water is scarce and leaching water expensive. Site-specific leaching on landscapes can reduce irrigation and leaching costs but is limited as most current irrigation systems do not have the flexibility to preferentially leach portions of a fairway. This study focused on creating and interpreting salinity maps before and after leaching in a landscape vegetation (golf course) that was considered to have salinity problems with different water applications on two different fairways. Efficacy of leaching was evaluated and likely factors impeding salinity reduction identified, specifically aeration. Aeration improved water penetration but ironically impeded salt leaching as it caused water to bypass the shallow soil depths. The analysis enables management changes to improve turfgrass quality. In one instance the likely cause of poor turf quality is attributed to low water holding capacity of a shallow soil and insufficient irrigation frequency. In future reclamation studies, the impact of soil disturbance (tillage and aeration) on salinity leaching should be further examined in conjunction with volumes of water applied and leached, enabling more rapid and efficient leaching (reduced water application).

\section{Material And Methods}




\subsection{Site description and Irrigation water quality}

This study was carried out in Dove Canyon Golf Course in Trabuco Canyon, California, US.

The main grass species in the fairways at the golf course is bermuda grass (Cynodon dactylon L.). Treated municipal wastewater has been used as irrigation water source. As analyzed, the water has an $\mathrm{EC}_{\mathrm{w}}$ of $1.32 \mathrm{dSm}^{-1}$ and a SAR (sodium adsorption ratio defined as $\mathrm{Na} /[(\mathrm{Ca}+\mathrm{Mg}) / 2]$ where units are $\mathrm{mmol}_{\mathrm{C}} \mathrm{L}^{-1}$ ) of 4.2 with cation composition of $\mathrm{Na}=7.65, \mathrm{Ca}=3.79$, and $\mathrm{Mg}=4.51$, where units are $\mathrm{mmol}_{\mathrm{C}}$

$\mathrm{L}^{-1}$. This salinity level, is acceptable for bermuda grass irrigation under good salinity management practices. Salinity tolerance of bermuda grass (Cynodon spp.) can vary greatly among different bermudagrass cultivars or phenotypes ${ }^{[27]}$. Bermuda grass is reported to be moderately salt sensitive $\left(\mathrm{EC}_{\mathrm{e}}\right.$ 3-6 dSm$\left.{ }^{-1}\right)$ or moderately tolerant $\left(6-10 \mathrm{dSm}^{-1}\right)$ depending on the cultivar examined ${ }^{[28]}$. Grieve ${ }^{[21]}$ et al., list the threshold EC at which growth decreases as $6.9 \mathrm{dS} \mathrm{m}^{-1}$.

Fairways 12 and 16 were evaluated for salinity effects as both had visible signs of stress and reduced vegetative cover. Sprinklers used for irrigation at the golf course had a theoretical application rate of 19.1 $\mathrm{mm} \mathrm{h}^{-1}$. Based on catch-can tests, the measured application rate was $17.2 \mathrm{~mm} \mathrm{~h}^{-1}$, hence all water applications based on irrigation time were corrected by a factor of 0.90 .

\subsection{Salinity survey and sampling design}

Salinity assessment was carried out by means of an EM38 instrument positioned vertically and horizontally in order to read both conductivity data at the same time (Fig. 1a). The $\mathrm{EM}_{\mathrm{v}}$ (vertical) reading penetrates to a depth of approximately 1.2-1.5 m, while the $\mathrm{EM}_{\mathrm{h}}$ (horizontal) reading penetrates to approximately $0.60-0.75 \mathrm{~m}^{[28]}$. The ESAP-95 program $^{[18,19,20]}$ was used to process the EM38 survey data and generate sampling plans for calibration using saturation extracts from soil cores. The algorithm in this program selects a limited set of calibration sites with desirable spatial and statistical characteristics based on analysis of $\mathrm{EC}_{\mathrm{a}}$ values and survey site location information using response surface design techniques ${ }^{[29]}$. Critical evaluation of response surface design and a unified sampling and modeling strategy for predicting soil property information from spatially referenced sensor data has been presented in detail by Lesch ${ }^{[30]}$. Thus, after collection and preliminary analysis of the electromagnetic induction signal data we collected sample soil cores from various locations within the field as indicated by the ESAP software. The accuracy of the salinity survey thus depends on the accuracy and precision used in both the survey and profile data acquisition processes, in addition to the correlation between these two data sets.

\subsection{Soil Sampling}

The ESAP software package identifies the optimal locations for soil sample sites from the $\mathrm{EC}_{\mathrm{a}}$ survey data. These sites are selected based on spatial statistics to reflect the observed spatial variability in $\mathrm{EC}_{\mathrm{a}}$ survey measurements. Generally, 6 to 20 sites are selected depending on the level of variability of the $\mathrm{EC}_{\mathrm{a}}$ 
measurements for a site. The optimal locations of a minimal subset of $\mathrm{EC}_{\mathrm{a}}$ survey sites are identified to obtain soil samples ${ }^{[15]}$. According to the EM38 readings and ESAP program outputs, $60 \mathrm{~cm}$ deep column samples were taken from the 10 calibration points per fairway (Fig. 2). The columns were divided into 0$15,15-30,30-45$ and $45-60 \mathrm{~cm}$ depths and then analyzed for water content, saturation percentage, $\mathrm{EC}_{\mathrm{e}}$ and $\mathrm{pH}_{\mathrm{e}}$ and major cation composition according to standard methods ${ }^{[31]}$ and cations by ICP). This procedure was repeated at the same sites for post leaching salinity analysis. A paired t-test was applied to statistically assess the changes between the pre- versus post-leaching salinity levels. At selected sites in each fairway we utilized Guelph permiameters to measure hydraulic conductivity using the site irrigation water.

\section{References}

1. Corwin, D. L. (2005). Apparent soil electrical conductivity measurements in agriculture. Computers and Electronics in Agriculture, 46: 11-43. doi-10.1016/j.compag.2004.10.005

2. Akramkhanov, A. (2010). Conversion factors to estimate soil salinity based on electrical conductivity for soils in Khorezm region, Uzbekistan. In M. Qadir, D. Wichelns, J. Oster, S.E. Jacobsen, S.M.A. Basra, \& R. Choukr-Allah (Eds.) Sustainable Management of Saline Waters and Salt-Affected Soils for Agriculture. Proceedings of the Second Bridging Workshop (pp 19-25), 15-18 November 2009, Aleppo, Syria.

3. Boettinger, J. L. (1997). Nondestructive assessment of rangeland soil depth to petrocalcic horizon using electromagnetic induction. Arid Soil Research and Rehabilitation. 11,372-390. doi$10.1080 / 15324989709381490$

4. Herrero, J., (2003). Soil salinity and its distribution determined by soil sampling and electromagnetic techniques. Soil Use Management, 19, 119-126 doi - 10.1111/j.1475-2743.2003.tb00291.x

5. Corwin, D. L. (2008). Past, present, and future trends in soil electrical conductivity measurements using geophysical methods. In, B.J. Allred, J.J. Daniels, \& M.R. Ehsani (eds) Handbook of agricultural geophysics.CRC Press, Taylor and Francis Group, Boca Raton,pp 17-44

6. Triantafilis, J. (2009). Field level digital mapping of cation exchange capacity using electromagnetic induction and a hierarchical spatial regression model. Australian Journal of Soil Research, 47,651663. doi-10.1071/SR08240

7. Lardo, E. Electromagnetic induction: a support tool for the evaluation of soil $\mathrm{CO} 2$ emissions and soil organic carbon content in olive orchards under semi-arid conditions. Geoderma. 264, 188-194 https://doi.org/10.1016/j.geoderma.2015.10.014 (2016).

8. Yao, R. J. (2016). Geostatistical monitoring of soil salinity for precision management using proximally sensed electromagnetic induction (EMI) method. Environmental Earth Sciences, 75,20, 1362. doi-10.1007/s12665-016-6179-z

9. Corwin, D. L. Protocols and Guidelines for Field-scale Measurement of Soil Salinity Distribution with ECa-Directed Soil Sampling. Journal of Environmental \& Engineering Geophysics. 18 (1), 1-25 
https://doi.org/10.2113/JEEG18.1.1 (2013).

10. Heil, K. (2017) The Application of EM38: Determination of Soil Parameters, Selection of Soil Sampling Points and Use in Agriculture and Archaeology. Sensors, 17, 2540. doi-10.3390/s17112540

11. Rhoades, J. D., (1999a) Geospatial measurements of soil electrical conductivity to assess soil salinity and diffuse salt loading from irrigation. In D.L. Corwin, K. Loague, \& T.R. Ellsworth (eds.) Assessment of non-point source pollution in the vadose zone. p. 197-215. Geophysical Monogr.

12. Sadler, E. J. (2007). New and future technology. In B.A. Steward \& D.R. Nelson (Eds) Irrigation of Agricultural Crops (2nd ed.) Agronomy Monograph No. 30(pp-609-626). Crop Science Society of America. Madison WI USA.

13. Carrow, R. N. Flitcroft, \& (2010). Precision turfgrass management: Challenges and field application for mapping turfgrass soil and stress. Precision Agric., 11:115-134. doi-10.1007/s11119-009-9136-y

14. Devitt, D. A. (2007). Spatial and temporal distribution of salts on fairways and greens irrigated with reuse water. Agronomy Journal, 99, 692-700. doi-10.2134/agronj2006.0183

15. Corwin, D. L. (2012). Laboratory and Field Measurements. In. W.W. Wallender, \& K. K. Tanji (Eds), Agricultural Salinity Assessment and Management. doi-10.1061/9780784411698\$4

16. Lesch, S. M. ESAP-RSSD version 2.30R. User manual and tutorial guide. Res. Report 148, November 2002 (USDA-ARS. George E. Brown, Jr., Salinity Laboratory, Riverside, California, 2002a).

17. Lesch, S. M. ESAP-SaltMapper version 2.30R. User manual and tutorial guide. Res. Report 149, December 2002 (USDA-ARS. George E. Brown, Jr.,, Salinity Laboratory, Riverside, California, 2002b).

18. Lesch, S. M. (2000). ESAP-95 Version 2.01R: User manual and tutorial guide. Res. Rep. 146. ARS George E. Brown, Jr., Salinity Lab., Riverside, CA,

19. Lesch, S. M. Spatial prediction of soil salinity using electromagnetic induction techniques: 1. Statistical prediction models: A comparison of multiple linear regression and cokriging. Water Resource Research. 31, 373-386 https://doi.org/10.1029/94WR02179 (1995a).

20. Amezketa, E. (2007). Soil salinity assessment using directed soil sampling from a geophysical survey with electromagnetic technology: a case study.Spanish Journal of Agricultural Research, 5(1),91-101. doi- 10.5424/sjar/2007051-225

21. Grieve, C. M. (2012). Plant salt tolerance, In W. W. Walender \& K.K. Tanji (eds) Agricultural Salinity Assessment and Management, ASCE Manuals and Reports on Engineering Practices No. 71 (2nd Ed.American Society of Civil Engineers, Reston VA, USA,1094 pp.

22. Shahba, M. (2010). Interaction effects of salinity and mowing on performance and physiologyof bermudagrass cultivars. Crop Science, 50, 2620-2631. Doi-10.2135/cropsci2010.04.0192

23. Marcum, K. B. (2006). Salinity tolerance and salt gland excretion efficiency of bermudagrass turf cultivars. Crop Science, 46,2571-2574. doi-10.2135/cropsci2006.01.0027

24. Xiang, M. (2017). Evaluating the salinity tolerance of clonal-type bermudagrass cultivars and an experimental selection. Horticulturtal Science 51(1),185-191. doi-10.21273/HORTSCI10773-16 
25. Ganjegunte, G. K. Soil Salinity of an Urban Park after Long-Term Irrigation with Saline Ground Water. Agron. J. 109, 3011-3018 https://doi.org/10.2134/agronj2017.04.0369 (2017).

26. Keren, R. (2012). Reclamation of saline, sodic, and boron affected soils. In, W. W. Walender \& K.K. Tanji, (eds) Agricultural Salinity Assessment and Management, ASCE Manuals and Reports on Engineering Practices No. 71 (2nd Ed.American Society of Civil Engineers, Reston VA, USA,1094 pp.

27. Huang, S. Current knowledge of bermudagrass responses to abiotic stresses. Breed. Sci. 69, 215226 https://doi.org/10.1270/jsbbs.18164 (2019).

28. Uddin, K. (2013). Salinity Tolerance Turfgrass: History and Prospects. The Scientific World Journal. doi-10.1155/2013/409413

29. Horney, R. (2005). Development of Practical Site-Specific Management Methods for Reclaiming SaltAffected Soil. Computers and Electronics in Agriculture 46, 379-397. doi-

10.1016/j.compag.2004.11.008

30. Lesch, S. M. (2005). Sensor-directed response surface sampling designs for characterizing spatial variation in soil properties. Computers \& Electronics in Agriculture, 46, 153-179. doi10.1016/j.compag.2004.11.004

31. US Salinity Laboratory Staff (1954). Diagnosis and improvement of saline and alkali soils. USDA Handbook 60, U.S. Government Printing Office, Washington, D. C.

\section{Figures}

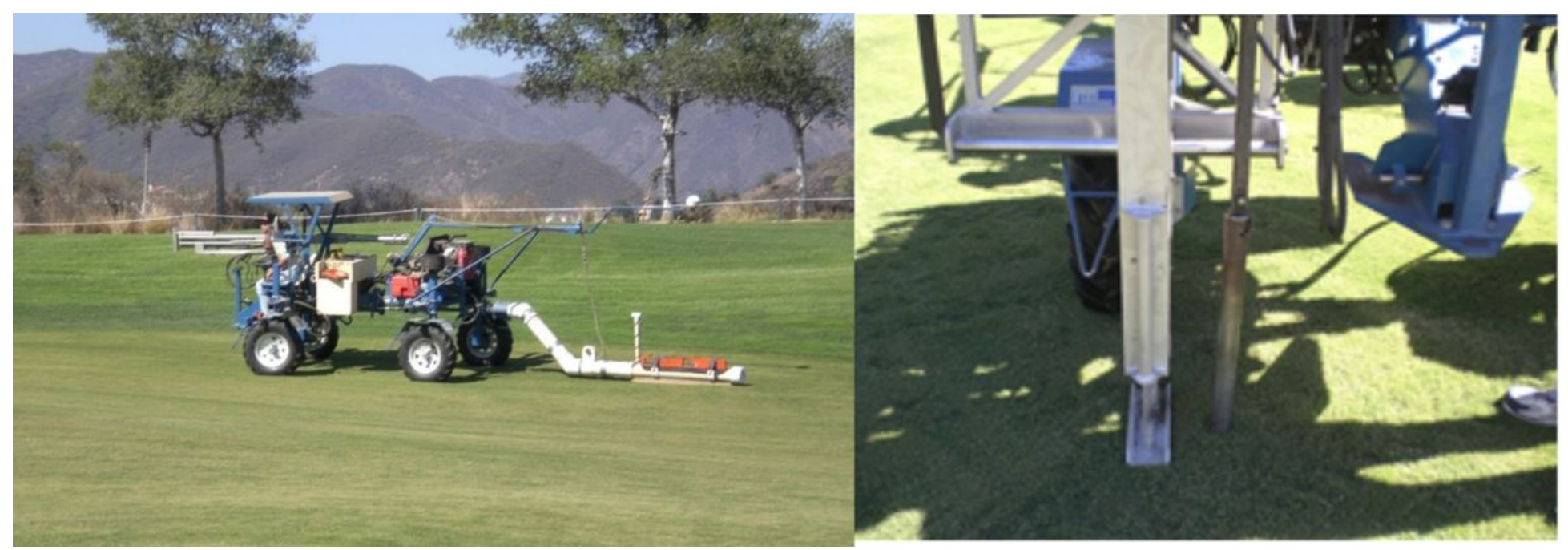

\section{Figure 1}

a) EM 38 remote sensing field vehicle with EM38 unit positioned for EC measurements at the site. b) Close up of soil coring instrument mounted to field vehicle. 


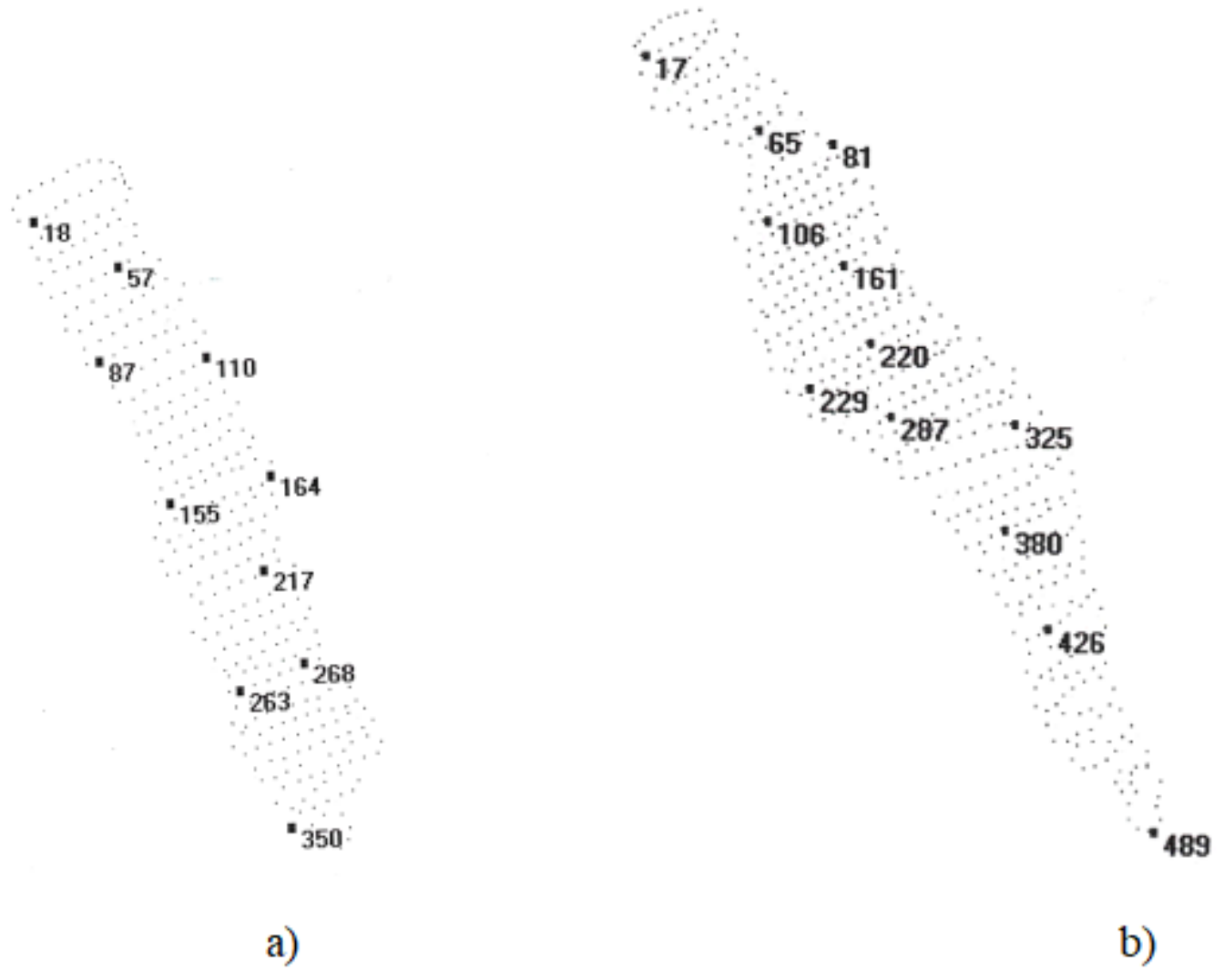

Figure 2

Soil Sampling design for a) fairway 16 and b) fairway 12 created via ESAP software 


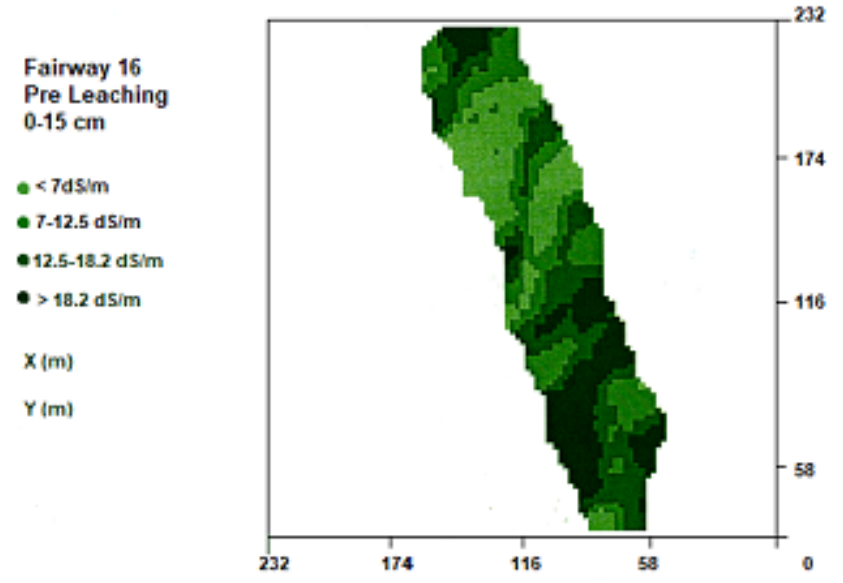

(a)

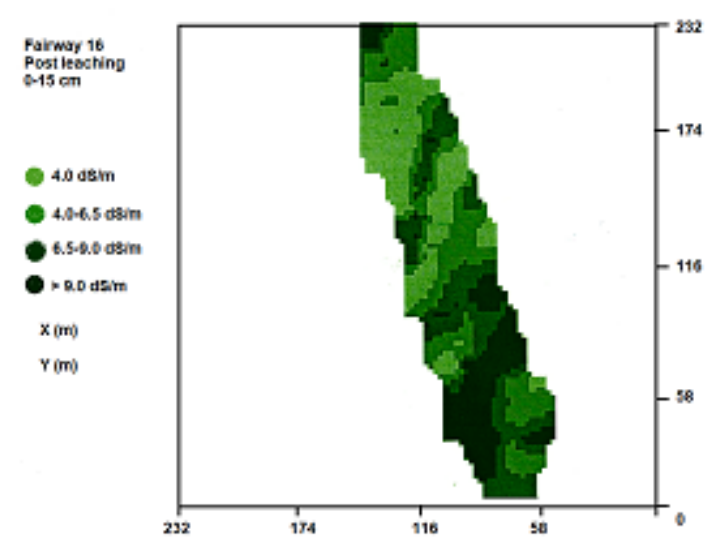

(c)

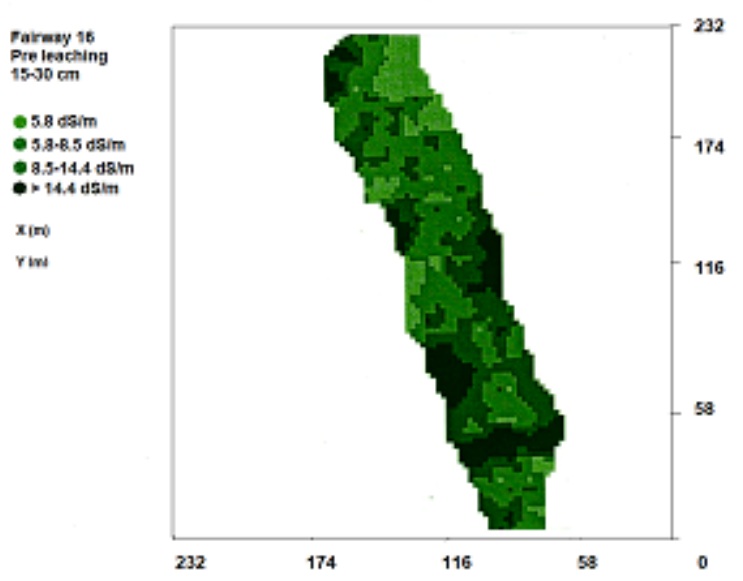

(b)

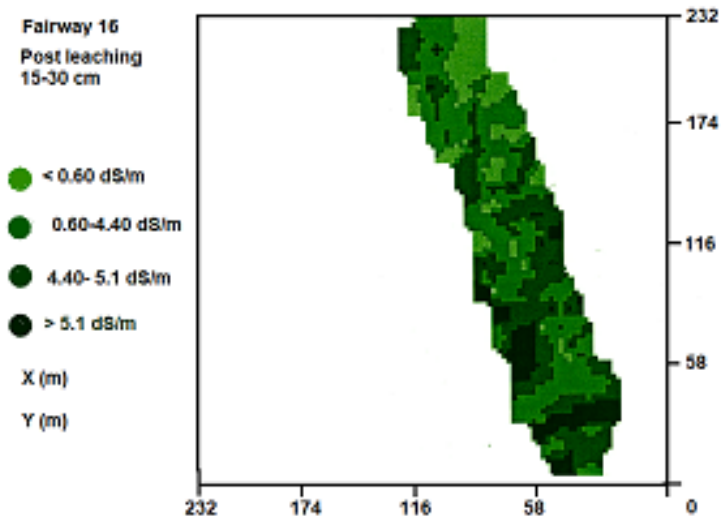

(d)

\section{Figure 3}

Pre-leaching a) 0-15 cm, b) $15-30 \mathrm{~cm}$ and post leaching c) 0-15 cm, d) $15-30 \mathrm{~cm}$ salinity maps (ECe) for fairway 16 created using ESAP 


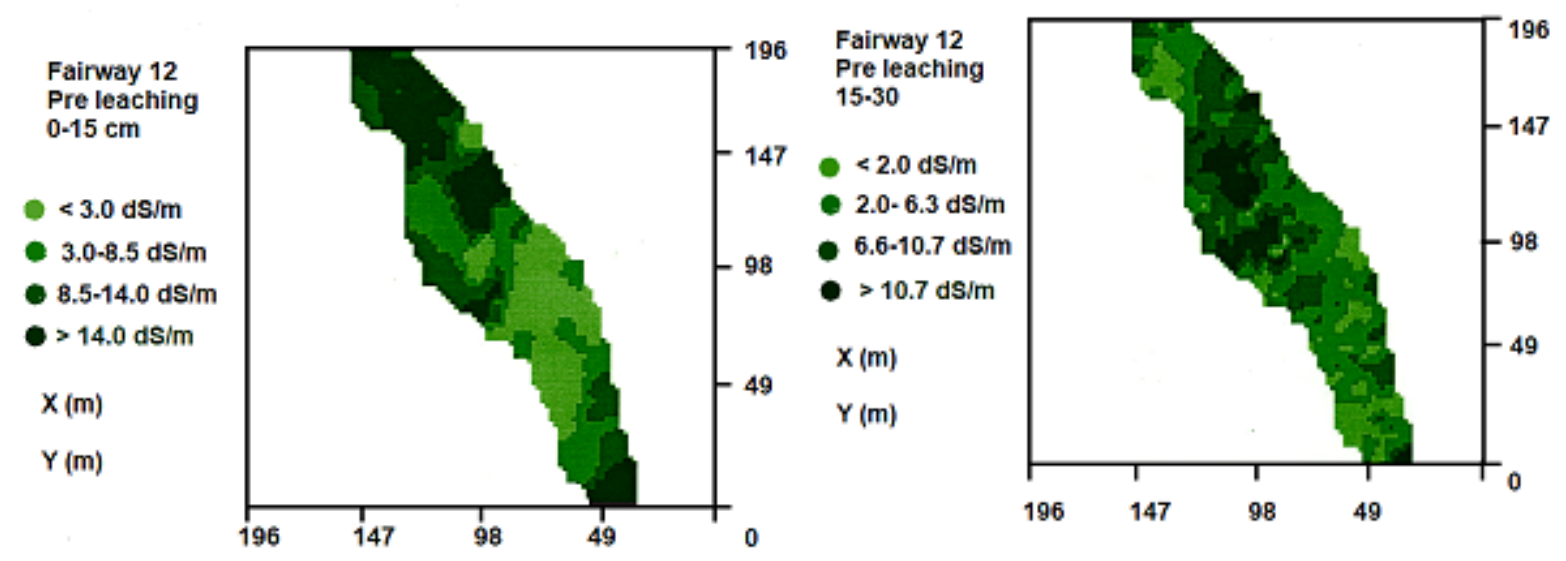

(a)

(b)

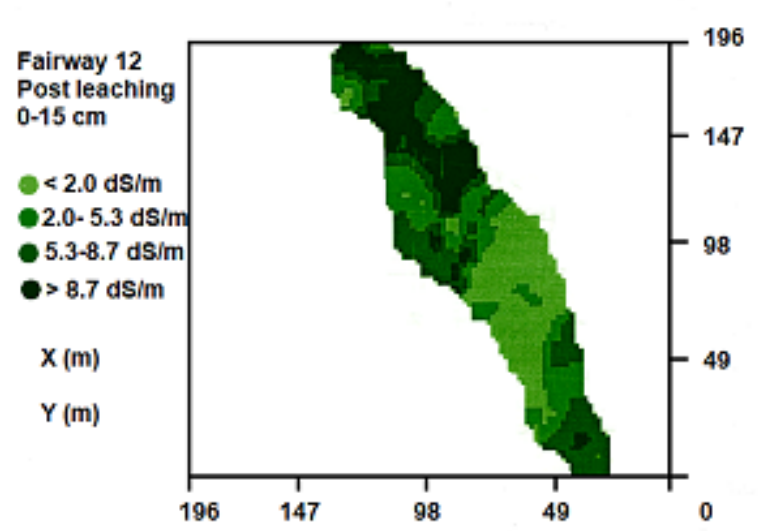

(c)

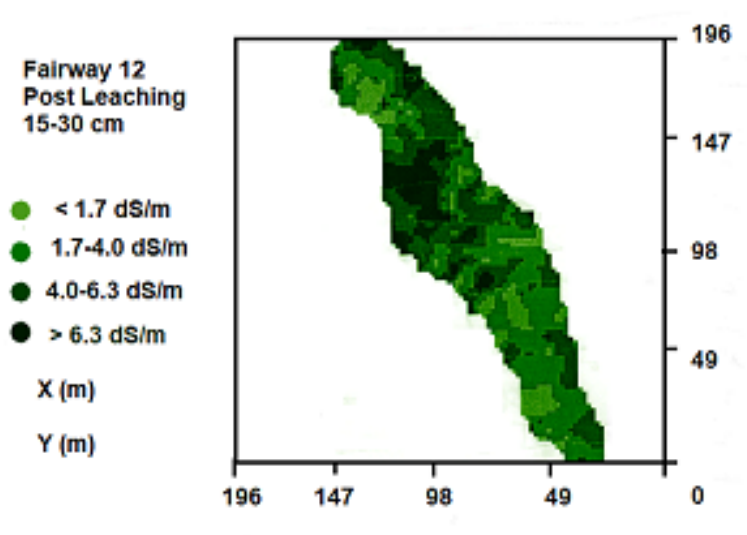

(d)

\section{Figure 4}

Pre-leaching a) 0-15 cm, b) $15-30 \mathrm{~cm}$ and post leaching c) 0-15 cm, d) $15-30 \mathrm{~cm}$ salinity maps (ECe) for fairway 12 created using ESAP 